\title{
Vilket resultat har socialtjänstens aktivering av socialbidragstagare? ${ }^{1}$
}

\author{
JENNY NYBOM
}

Med logistiska regressioner analyseras samband mellan socialtjänstens aktivering av socialbidragstagare under ett år och inkomster frän arbete respektive socialbidrag påföljande två år. 351 ärenden från fyra kommuner ingår.

Enligt resultaten var aktiveringsinsatser inr.ktade på resurser som utbildning och praktik på en reguljär arbetsplats kopplade till att klienterna fick arbete. Sanktioner, som är en del av aktivering, var kopplade till att fortsätta ha socialbidrag. Sanktioner verkade kunna ha olika resultat för olika grupper av bidragstagare alternativt beroende på vilken aktiveringsinsats klienten fätt.

\section{Inledning och syfte}

Det finns relativt lite svensk forskning om hur socialtjänstens hantering av enskilda socialbidragstagare bidrar till eller motverkar att klienter kommer i arbete. Det är en kunskapsbrist som återkommande uppmärksammas i socialtjänst- och väl-

Jenny Nybom, fil.dr i socialt arbete, Institutionen för socialt arbete, Stockholms universitet, arbetar på Socialstyrelsen. färdsforskning (se t.ex. Jonasson 1989; Svedberg 1994; Geldof 1999; Hvinden 1999; Bergmark 2000; Franzén 2003; Halvorsen \& Jensen 2004; Salonen 2006).

Ett möjligt skäl till den begränsade

1 Tack för konstruktiva synpunkter i artikelskrivandet riktas till de anonyma lektörerna. Vidare till mina handledare Bo Vinnerljung, Tommy Lundström och Åke Bergmark samt Hugo Stranz och Lars Brännström, samtliga verksamma på Institutionen för socialt arbete, Stockholms universitet. 
forskningen om hur socialtjänsten kan hjälpa socialbidragstagare till arbete kan vara kunskapen om den starka kopplingen mellan arbetslöshet och socialbidragstagande (se t.ex. Korpi 1971; Gustafsson 1984; Stenberg 1998; Bergmark 2000; Halleröd 2003; Brännström \& Stenberg 2007). I tider av arbetslöshet har socialbidrag betalats ut i väntan på en konjunkturvändning. När vändningen sedan kommit, har arbetslösa socialbidragstagare fått arbete medan, enkelt uttryckt, personer med försörjningshinder har blivit kvar på socialbidrag. Så har mönstret sett ut under lång tid men sedan minst ett decennium märks att olika grupper av arbetslösa socialbidragstagare i ökad utsträckning "blir kvar" i socialbidragstagande också under gynnsammare konjunkturer. Det handlar bland annat om unga personer, personer med invandrarbakgrund, ensamstående mödrar och personer som saknar gymnasieutbildning (Bergmark \& Bäckman; 2004, 2007, 2011; Bergmark \& Palme 2003; Bäckman 2011; Bäckman \& Nilsson 2011; Franzén 2002; Socialstyrelsen 2006, 2010; Stranz \& Wiklund 2011).

Det socialpolitiska svaret på utvecklingen har varit en decentralisering av arbetsmarknadspolitiken. Sverige och Norden har en lång tradition av att satsa en relativt stor andel av BNP på statliga arbetsmarknadspolitiska program. Sedan 1990-talet har aktiveringspolitiken i Sverige, liksom i OECD-länderna generellt, handlat om att stärka kraven på arbetslösa socialbidragstagare att delta $i$ aktiveringsinsatser (det som i kommunerna ofta benämns som arbetsmarknadsprojekt) för att ha rätt till socialbidrag (se t.ex.
OECD 1994; Eardly et al. 1996; Heikkilä \& Keskitalo 2001; Lødemel \& Trickey 2001; Johansson 2001). I Sverige har många kommuner upplevt att socialbidragstagare får begränsad tillgång de statliga arbetsmarknadsprogrammen och därför utvecklat egna aktiveringsinsatser.

Parallellt har aktiveringspolitiken stärkt socialtjänstens roll i arbetet med att hjälpa socialbidragstagare in på arbetsmarknaden. Detta manifesterades år 1998 med två nya paragrafer i socialtjänstlagen som dels handlar om socialtjänstens uppgift att erbjuda och/eller kräva deltagande i kompetenshöjande aktiveringsinsatser, dels om socialtjänstens mandat att ge sanktioner till klienter som inte uppfyller kraven på aktivitet (prop. 1996/97:124). Paragraferna återspeglar den kombination av stöd och kontroll som alltid präglat samhällets hantering av fattiga (se t.ex. Lindqvist \& Marklund 1995; Tengvald 1995; Sunesson 1981, 2002; Junestav 2004). Många svenska och nordiska studier drar paralleller mellan den aktuella aktiveringspolitiken och fattigvården, där olika former av "arbetstest" användes för att skilja värdiga bidragstagare, exempelvis sjuka personer och ensamma mödrar, från ovärdiga bidragstagare som ofta var män som inte uppfyllde sitt försörjningsansvar (se t.ex. Lødemel \& Schulte 1992; Lødemel 1997; Johansson 2001; Giertz 2004; Ulmestig 2006; Salonen 2006).

Den huvudsakliga målgruppen för aktiveringsparagraferna år 1998 var bidragstagare under 25 år (prop. 1996/97:124). Nyligen gjordes en ändring av paragraferna som utvidgade målgruppen, för vilken socialtjänsten kan ställa krav om 
aktiveringsinsatser och ge sanktioner, till att omfatta alla socialbidragstagare oavsett ålder (prop. 2012/13:94).

Med sanktioner menas avslag på socialbidragsansökan för att klienten inte deltagit i hänvisad aktiveringsinsats eller för att klienten inte varit tillräckligt aktiv för att bli självförsörjande genom exempelvis arbetssökande. När enbart termen "aktivering" används i den vidare texten avser den både aktiveringsinsatser och sanktioner.

Studier som handlar om hur socialbidragstagare selekteras till aktiveringsinsatser och sanktioner tyder på att parallellen till fattigvården är relevant (se t.ex. Lødemel 2002). Tidigare delstudier i detta forskningsprojekt visar att kvinnor generellt sett - och särskilt mödrar - fick färre och delvis andra aktiveringsinsatser än män, och sanktioner riktades främst mot äldre svenska män. Aktiveringsinsatser, och i än högre grad sanktioner, kunde kopplas till om klienten uppfattades ha bristande arbetsmotivation enligt sin handläggare. Aktiveringsinsatser inriktade på resurser som utbildning och arbetspraktik (resursaktivering i den vidare texten) riktades sällan till personer som saknade just utbildning och arbetserfarenhet. Klienter under 25 år fick ofta aktivering $\mathrm{i}$ form av jobbträning eller arbetssökande i kommunal regi (jobbaktivering i den vidare texten), trots att de ofta saknade utbildning och arbetserfarenhet (Nybom 2011b)2. I sin tillämpning tycks aktivering återspegla en traditionell

2 Skillnaderna gäller efter kontroll för kommunala skillnader i tillämpningen av aktiveringsinsatser och sanktioner. "arbetstest"-logik, sammanflätad med en könslogik.

Studier på organisations- och institutionell nivå tyder på att aktivering tillämpas mekaniskt, som ett påbud uppifrån, och inte utifrån individuella bedömningar (se t.ex. Hjertnér Thorén 2005, Hedblom 2005). Detta kan vara en förklaring till att aktiveringspolitiken, såsom den tillämpas bland socialbidragstagare, förefaller att upprätthålla, snarare än att upphäva fattigvårdens traditioner.

Det finns relativt mycket forskning om de statliga arbetsmarknadsprogrammen. Den utgår i regel från de data som finns tillgängliga i arbetsförmedlingarnas register. I dessa studier kan inte socialbidragstagare som grupp urskiljas, eftersom uppgifter om försörjningskälla inte registreras på arbetsförmedlingen. Kommunala aktiveringsinsatser ingår inte heller i den forskningen. Eftersom deltagande i socialtjänstens aktiveringsinsatser sällan dokumenteras systematiskt, finns det få studier om aktiveringens resultat med fokus på gruppen socialbidragstagare.

Syftet med den här studien är att undersöka hur aktiveringsinsatser och sanktioner är kopplade till om socialbidragstagare kommer i arbete eller fortsätter att ha socialbidrag. Detta för att bättre kunna förstå och värdera konsekvenserna av socialtjänstens tillämpning av aktiveringspolitiken.

\section{Arbete som önskvärt utfall}

Artikeln utgår ifrån att lönearbete är ett önskvärt utfall, medan varaktigt social- 
bidragstagande är mindre önskvärt. Den värderingen baseras på studier som visar att socialbidragstagare främst önskar sig ett arbete, att de vill slippa "gå på bidrag" och att de önskar få stöd från socialtjänsten för att få arbete (se t.ex. Puide 1985; Fridberg 1993; Jonsson 2001; Karlsson 2006). Enligt de studier som specifikt undersökt arbetsmotivation, har arbetslösa socialbidragstagare samma arbetsmotivation som befolkningen i genomsnitt (se t.ex. Bergmark 1991; Jonasson 1996; Furåker 1997; Nordenmark 1999; Boll \& Christensen 2002). Arbetslösa kvinnor och arbetslösa med invandrarbakgrund, såväl kvinnor som män, har visat sig ha särskilt hög arbetsmotivation (Nordenmark 1999; Hedblom 2004). Många socialbidragstagare upplever skam och maktlöshet i situationen som bidragstagare (se t.ex. Gunnarsson 1993; Jönsson \& Starrin 1999; Ulmestig 2009; Angelin 2009). Dessa resultat understryker vikten av att undersöka om socialtjänsten bidrar till eller motverkar socialbidragstagares övergång till arbete.

\section{Kontroll och stöd $\mathbf{i}$ aktiveringspolitiken}

Forskning om aktiveringspolitik urskiljer ofta två idealtypiska modeller av aktivering, som här kallas för jobbaktivering och resursaktivering. Enkelt uttryckt kan modellerna beskrivas som morot och piska, där resursaktivering är moroten och jobbaktivering med tillhörande sanktioner är piskan. Jobbaktivering anses främst handla om kontroll av socialbidragstagare och på så sätt vara besläktad med fattigvården. Resursaktivering anses vara mer stödjande, med syftet att förbättra socialbidragstagarens position visavi arbetsmarknaden, genom utbildning och arbetserfarenhet. På en teoretisk nivå förknippas jobbaktivering med användning av sanktioner. Jobbaktivering och sanktioner tillsammans, antas ofta fylla en avskräckande funktion som får individen att avstå från att söka socialbidrag om han eller hon inte verkligen behöver det. Resursaktivering liknas ofta vid statlig aktivering och antas därför vara mindre kopplad till sanktioner (se t.ex. Lødemel 1997; Lødemel \& Trickey 2001; van Berkel \& Horneman Møller 2002; Hanech 1999; Heikkilä 1999).

I en tidigare delstudie analyserades och kategoriserades innehållet i samtliga aktiveringsinsatser som klienterna deltagit i. Där bekräftades relevansen i att skilja på jobbaktivering och resursaktivering. Samma delstudie visade att sanktioner var lika vanliga bland de klienter som deltog i resursaktivering som bland dem som deltog i jobbaktivering. Det motsäger aktiveringsforskningens mer eller mindre explicita föreställning om sanktionernas roll i de idealtypiska modellerna om aktivering. Ett ytterligare resultat var att fler än hälften varken fick aktiveringsinsatser eller sanktioner (Nybom 2011a).

Sammantaget betyder det att när aktiveringspolitiken omsätts i praktiken kan det resultera i olika kombinationer av aktiveringsinsatser och sanktioner. 


\section{Tidigare forskning om resultat av aktivering}

Flera studier om hur det går för socialbidragstagare har undersökt utfallet i form av avslutat bidragstagande, det vill säga hur stor andel som lämnar socialbidragstagandet bakom sig. Enligt studierna lämnar omkring 25-35 procent av klienterna, generellt sett, bidragstagandet. Det är oklart i vilken utsträckning det sker på grund av arbete (se t.ex. Milton \& Bergström 1998; Lødemel et al. 2004; Ekström 2005; Palm \& van Eyck 2007). En longitudinell registerstudie om avslutat bidragstagande tyder dock på att endast runt 20 procent av "avslutarna" ingår i kärnarbetskraften efter ett år (Bergmark \& Bäckman 2011).

Få nordiska studier har kopplat aktivering, som inkluderar både aktiveringsinsatser och sanktioner, till arbete eller fortsatt bidragstagande. Ett undantag är ett försöksprojekt med aktiva insatser för arbetslösa bidragstagare, som genomfördes innan de nya paragraferna i socialtjänstlagen infördes. Socialbidragstagarnas försörjningssituation följdes upp i tre år. Omkring en tredjedel i den relativt belastade klientgruppen fick ett stadigvarande arbete och ytterligare fler arbetade periodvis (Jonasson 1989). Noggranna utredningar av klientens situation, ett målinriktat arbete enligt en plan samt tid och engagemang från personalen, identifierades som centrala verktyg för att lyckas hjälpa klienterna in på arbetsmarknaden. Milton \& Bergström (1998) genomförde en utvärdering av försörjningssituationen bland klienter i en stadsdel i
Uppsala som tillämpade den så kallade Uppsalamodellen. Uppsalamodellen betonade individens eget ansvar genom obligatoriska krav på arbetssökande ett visst antal timmar per dag. Uppsalamodellens klienter jämfördes med klienter från en stadsdel som inte tillämpade motsvarande arbetssätt. Forskarna fann inga skillnader i avslutat bidragstagande mellan grupperna. En tendens var att Uppsalamodellens klienter återkom för bidrag i högre utsträckning än jämförelsegruppen.

Under senare tid har Dahlberg, Johansson och Mörk (2008) undersökt hur införandet av aktiveringskrav i form av generella hänvisningar av socialbidragstagare till de så kallade jobbtorgen i Stockholm har påverkat in- och utflöde från bidragstagandet. De finner en viss minskning av inflöde till socialbidragstagande på gruppnivå. Uppgifter om aktivering och sanktioner på individnivå saknas i denna studie, och den belyser därför inte kopplingen mellan socialtjänstens faktiska arbete och in- och utflöde till bidragstagande.

I en studie från Norge visar Dahl (2003) att aktiveringsinsatser saknar effekter på arbete och inkomster efter att såväl observerbara som icke-observerbara selektionseffekter till aktiveringsdeltagande hanterats. I en studie om aktivering i sex europeiska länder konstateras att variationen mellan olika länders selektion till aktivering gör det svårt att göra jämförelser av effekten av aktivering mellan länder (Lødemel 2002).

Beträffande internationell forskning har Giertz (SOU 2007:2) gjort en översikt om effekter av aktivering respektive sanktioner med fokus på socialbidragstagare. 
Av den framgår att aktiveringsinsatser som liknar vanligt arbete, till exempel praktik i privata företag (vilket ryms inom resursaktivering i denna artikel), har större positiva effekter än exempelvis arbetsträning i kommunal sysselsättningsverksamhet. Här framgår också att grupper selekteras till aktiveringsinsatser på olika grunder och att aktiveringsinsatser och sanktioner tycks ha olika effekter på olika grupper av bidragstagare. MalmbergHeimonen (2005) kommer fram till samma resultat, nämligen att påtvingat deltagande i aktivering riskerar att förlänga en persons arbetslöshetsperioder, vilket här skulle motsvaras av socialbidragsperioder. Ett flertal internationella studier visar att sanktioner tenderar att riktas mot personer med många försörjningshinder och som följaktligen står långt från arbetsmarknaden (se t.ex. Riccio \& Hasenfeld 1996; Hasenfeld, Ghose \& Larson 2004). När denna skevhet i tillämpningen kontrolleras tycks sanktioner kunna påskynda övergång till arbete (se t.ex. Pavetti, Derr \& Hesketh, 2003; Cherlin et al. 2002; van der Berg et al. 2004; Peck 2007).

En översikt av experimentella utvärderingar av amerikanska aktiveringsinsatser (så kallade welfare-to-work-program) visar också att aktivering kan ha olika effekter för olika grupper (Smedslund et al. 2006). Analyserna tyder på att aktiveringsprogram skulle vara mer effektiva om de var inriktade på kvinnor, på icke-vita målgrupper och hade ett frivilligt deltagande. Frivilligt deltagande hade större positiv effekt än obligatoriskt, men resultatet är osäkert eftersom randomiseringen till aktiveringsinsatserna inte gjordes uti- från frivillighet/sanktioner och skillnaden inte var signifikant. Aktiveringsinsatserna hade små positiva effekter; 33 personer måste delta i aktivering för att ytterligare en person ska uppnå anställning, jämfört med grupper som inte får aktivering (Smedslund et al. 2006).

Ett genomgående drag i forskningen är en ambition att isolera effekter (i regel på inkomst av arbete) av aktiveringsinsatser respektive effekten av sanktioner. Samtidigt pekar både svensk och internationell forskning på att aktivering i praktiken består av kombinationer av aktiveringsinsatser och sanktioner. Trots detta finns det få, om ens några, studier som på individnivå undersökt hur olika kombinationer av aktiveringsinsatser och sanktioner påverkar socialbidragstagares sannolikhet att få arbete eller vara kvar på socialbidrag.

Innevarande material (beskrivs närmare i nästa avsnitt) innehåller uppgifter om både aktiveringsinsatser och sanktioner, vilket gör det möjligt att undersöka samband mellan de två aktiveringsinslagen separat samt aktiveringsinsatser och sanktioner i olika kombinationer. Materialets begränsade storlek innebär dock att en viss osäkerhet kommer att omgärda de samband som undersöks. Mot bakgrund av samhällets förhoppningar och åtföljande krav på socialtjänsten att hjälpa socialbidragstagare till arbete med aktivering, kan det ändå vara motiverat att tillvarata alla möjligheter att utforska hur aktiveringens olika inslag verkar fungera för klienterna. 


\section{Material, operationaliseringar och analyser}

Datamaterialet kommer från ett forskningsprojekt om socialtjänstens arbete $i$ enskilda socialbidragsärenden. Projektet genomfördes vid Centrum för utvärdering av socialt arbete (CUS)/Institutet för utveckling av metoder i socialt arbete (IMS) under åren 2002-2004 i kommunerna Karlstad, Norrköping, Upplands Väsby och Östhammar (Nybom et al. 2005).

Urvalet av ärenden gjordes av forskningspersonal (assistenter eller forskare). Dessa infann sig varje morgon under veckovisa perioder på respektive socialkontor och valde där slumpmässigt ut ett av de inbokade besöken på socialkontorens besökslistor. Datainsamlingen pågick i två till tio månader, beroende på klientinflödet i respektive kommun. Efter det först framslumpade besöket valdes därefter besök i den ordning de var inbokade under dagen (Nybom et al. 2005). Klient och handläggare i valda ärenden tillfrågades om att delta i studien. Nittio procent av klienterna och samtliga socialarbetare valde att delta. Totalt valdes 568 ärenden in $\mathrm{i}$ arbetssättsstudien.

I samband med det valda besöket gjordes strukturerade intervjuer separat med klient och socialarbetare, som bland annat handlade om klientens bakgrundsuppgifter. Cirka ett år senare genomfördes strukturerade intervjuer med de aktuella socialarbetarna i varje ärende, med frågor om klienternas försörjningshinder, aktiveringsinsatser och sanktio- ner under det gångna året. För flertalet klienter inföll undersökningsåret under 2003. För ett fåtal klienter avslutades undersökningsperioden i början av 2004. I Norrköping studerades klienter vid ett av fyra kontor (övriga kommuner hade endast ett kontor). Kontoret arbetade endast med klienter över 25 år.

Kopplingen mellan aktiveringsinsatser och sanktioner och arbete respektive fortsatt socialbidragstagande är främst relevant för klienter som har ett substantiellt behov av socialbidrag (inte tillfälligt) och som inte är pensionerade eller sjukskrivna på heltid. I denna grupp kan socialtjänsten förväntas använda aktivering för att hjälpa klienterna till arbete. För att urskilja denna grupp i materialet inkluderades endast klienter som ansökt om socialbidrag minst sex månader under en tvåårsperiod före studien, och som inte erhöll socialbidrag som en ersättning för eller komplettering till sjukersättning/sjukpension eller ålderspension. Dessa kriterier uppfylldes för 372 klienter. I regisiteruppföljning av inkomster (beskrivs nedan) saknade SCB uppgifter för 21 individer. Totalt ingår 351 individer $i$ analyserna.

De olika typerna av aktiveringsinsatser består av de arbetsmarknadsprojekt som socialtjänsten i varje kommun hade möjlighet att erbjuda eller hänvisa socialbidragstagare till. Såväl statligt som kommunalt organiserade projekt ingår. I studiens inledningsskede insamlades uppgifter om de olika arbetsmarknadsprojekten. Projektens innehåll undersöktes via intervjuer med projektpersonal och genom kommunens egen dokumentation. 
I formuläret vid den andra intervjun med socialarbetarna ingick frågor om huruvida klienten deltagit i något av de arbetsmarknadsprojekt som identifierats i respektive kommun. I Norrköping, där endast ett av fyra kontor ingick i studien, hade samtliga kontor tillgång till samma aktiveringsinsatser (Nybom et al. 2005).

Utifrån data i studien har variabler som fångar aktivering skapats (se tabell 1). De två centrala aktiveringsinslagen är aktiveringsinsatser, här uppdelade $\mathrm{i}$ två dikotoma variabler, jobbaktivering och resursaktivering, och sanktioner. Till jobbaktivering räknas jobbsökaraktiviteter och jobbträning. Jobbträningen genomfördes ofta på för ändamålet skapade second-hand-butiker och verkstäder och inte på reguljära arbetsplatser. Jobbaktiveringen var sällan tidsbegränsad. Cirka 80 procent av jobbaktiveringen var kommunalt organiserad. Som resursaktivering räknas utbildningar som exempelvis sfi (svenska för invandrare), yrkesinriktade kurser, strukturerade och tidsbegränsade program som innehöll beskrivna delmoment såsom cv-skrivande, samtal och information om arbetsmarknaden. Till resursaktivering räknas också arbetspraktik på en reguljär arbetsplats. Ungefär hälften av resursaktiveringen skedde i statlig regi och hälften $i$ kommunal regi (se vidare Nybom 2011a).

Variabeln sanktioner (se tabell 1) är dikotom och baserad på avslag i respektive ärende under året som undersöktes. Beslut om avslag inhämtades från klienternas akter före den andra intervjun med socialarbetare i respektive ärende. Under intervjun fick socialarbetaren ange motiv till samtliga avslag under perioden. Sanktioner skiljdes från andra avslag (på grund av exempelvis för höga inkomster eller ofullständig ansökan) genom att dessa motiverades med klientens bristande aktivitet (att klienten t.ex. inte gått till arbetsförmedlingen, inte sökt tillräckligt många arbeten eller haft bristande närvaro i aktiveringsinsatser). Sanktioner kunde gälla hela eller delar av bidraget men gällde oftast en del av det. Endast ett fåtal personer hade fått mer än en sanktion under året.

Aktiveringskombinationerna (se tabell 1) består av möjliga kombinationer av aktiveringsinsatser och sanktioner. Aktiveringskombinationerna utgör dikotoma variabler och är ömsesidigt uteslutande. Ingen klient har fått flera kombinationer. Att varken få aktiveringsinsats eller sanktion betraktas som en insats i sig, den kallas helt enkelt Ingen aktivering. Enligt aktiveringsparagraferna i socialtjänstlagen ska personer som är i behov av kompetenshöjande åtgärder erbjudas aktiveringsinsatser. Det betyder att Ingen aktivering kan vara "rätt" insats för de personer som inte bedöms vara i behov av kompetenshöjande åtgärder.

\section{Tabell 1.}

Deskriptiva uppgifter om aktiveringsvariablerna (oberoende variabler) som ingår $\mathrm{i}$ analyserna, operationalisering och fördelning. Procent $(n=351)$.

Som framgår av tabellen är den vanligaste situationen att klienten fått Ingen sanktion, det vill säga varken fått aktiverings- 


\begin{tabular}{|c|c|c|}
\hline $\begin{array}{l}\text { Aktiveringsvariabler } \\
\text { Aktiveringsinslag }\end{array}$ & Operationalisering & $\begin{array}{l}\text { Andel av } \\
\text { samtliga }\end{array}$ \\
\hline Jobbaktivering & $\begin{array}{l}\text { Deltagande i jobbträning på ej reguljär arbetsplats eller i jobbsö- } \\
\text { karverksamhet, i regel ej tidbestämt. }\end{array}$ & 17,7 \\
\hline Resursaktivering & $\begin{array}{l}\text { Deltagande i utbildning, praktik på reguljär arbetsplats eller } \\
\text { expertutredning av arbetsförmåga, i regel tidbestämt. }\end{array}$ & 11,7 \\
\hline Sanktion & $\begin{array}{l}\text { Avslag eller nedsättning av socialbidrag för bristande närvaro i } \\
\text { aktiveringsinsatser eller för bristande aktivitet för att få arbete. }\end{array}$ & 19,1 \\
\hline Ingen aktivering & Ej deltagit i aktivering och ingen erfarenhet av sanktion. & 61,0 \\
\hline \multicolumn{3}{|l|}{ Aktiveringskombinationer } \\
\hline Jobbaktivering och ingen sanktion & Deltagande i jobbaktivering, ingen erfarenhet av sanktion. & 12,3 \\
\hline Jobbaktivering och sanktion & Deltagande i jobbaktivering samt erfarenhet av sanktion. & 5,4 \\
\hline $\begin{array}{l}\text { Resursaktivering och ingen sank- } \\
\text { tion }\end{array}$ & Deltagande i resursaktivering, ingen erfarenhet av sanktion. & 7,7 \\
\hline Resursaktivering och sanktion & Deltagande i resursaktivering samt erfarenhet av sanktion. & 4,0 \\
\hline Sanktion och ingen aktivering & Ej deltagit i någon aktivering, ingen erfarenhet av sanktion. & 9,6 \\
\hline
\end{tabular}

\section{Tabell 1}

insats eller sanktion. Knappt en femtedel av klienterna har fått Sanktion respektive Jobbaktivering och strax över 10 procent av klienterna har fått Resursaktivering.

När det gäller aktiveringskombinationerna har cirka 10 procent av klienterna fått Jobbaktivering och sanktion och Sanktion och ingen aktivering. Något färre har fått Resursaktivering och ingen sanktion och de minst vanliga insatserna är Jobbaktivering och sanktion och Resursaktivering och sanktion, vilket runt 5 procent av klienterna fått del av.

I analyserna kontrolleras för klientvariabler bestående av klienternas karaktäristika och försörjningshinder (se tabell 2) eftersom vi vet att de påverkar såväl selektionen till aktiveringsinsatser som sanktioner och chanser att lämna socialbidragstagande för arbete. Klientkaraktäris- tika omfattar demografiska uppgifter som kön, ålder, bakgrund (svensk bakgrund och invandrarbakgrund) och hushållssituation, vilka är hämtade från intervjuerna med klienterna.

\section{Tabell 2.}

Deskriptiva uppgifter, klient- och kommunvariabler (kontrollvariabler), operationalisering och fördelning. Procent $(\mathrm{n}=$ 351).

Uppgifter om klienternas försörjningshinder bygger på en fråga till socialarbetarna som löd: Anser du att den här klienten har några hinder för att fä eller behailla ett arbete? Socialarbetarna fick kryssa för valfritt antal svar bland fasta svarsalternativ (se vidare Nybom 2008). Uppgif- 


\begin{tabular}{|c|c|c|c|}
\hline \multicolumn{2}{|c|}{ Klientvariabler } & Operationalisering & $\begin{array}{l}\text { Andel av } \\
\text { samtliga }\end{array}$ \\
\hline Kön & Kvinnor & Klientens egen uppgift & 50,7 \\
\hline Ålder & 25 år och yngre & Klientens egen uppgift & 27,4 \\
\hline Bakgrund & Svensk & Minst en förälder är född i Sverige & 61,8 \\
\hline & Utländsk & Båda föräldrarna är födda utomlands & 38,2 \\
\hline \multicolumn{4}{|c|}{ Hushållssituation } \\
\hline & Sammanboende utan barn & Klientens egen uppgift & 25,6 \\
\hline & Sammanboende med barn & Klientens egen uppgift & 12,0 \\
\hline & Ensamstående & Klientens egen uppgift & 35,3 \\
\hline & Ensamstående med barn & Klientens egen uppgift & 27,1 \\
\hline Socialbid & $\begin{array}{l}\text { ragsomfattning } \\
\text { Låg (<12 av } 24 \text { mån) }\end{array}$ & $\begin{array}{l}\text { Antal månader som klienten sökt socialbidrag samman- } \\
\text { lagt under året, före studien och det undersökta året. } \\
\text { Beslut noterades i akter och stämdes av med respektive } \\
\text { handläggare. }\end{array}$ & 31,1 \\
\hline & Måttlig (12-19 av 24 mån) & & 36,2 \\
\hline & Hög (> 20 av 24 mån) & & 32,7 \\
\hline \multicolumn{2}{|c|}{ Bristande kvalifikationer } & $\begin{array}{l}\text { Socialarbetaren uppger att klienten saknar utbildning } \\
\text { och/eller arbetserfarenhet. }\end{array}$ & 55,3 \\
\hline \multicolumn{2}{|l|}{ Ohälsa } & $\begin{array}{l}\text { Socialarbetaren uppger att klienten har diagnostiserad } \\
\text { fysisk och/eller psykisk ohälsa. }\end{array}$ & 29,9 \\
\hline \multicolumn{2}{|l|}{ Missbruk } & $\begin{array}{l}\text { Socialarbetaren uppger att klienten haft ett långvarigt, } \\
\text { periodvis återkommande och/eller pågående missbruk. }\end{array}$ & 17,9 \\
\hline \multicolumn{2}{|c|}{ Bristande motivation } & $\begin{array}{l}\text { Socialarbetaren uppger att klienten har bristande moti- } \\
\text { vation till arbete. }\end{array}$ & 17,9 \\
\hline \multicolumn{4}{|c|}{ Kommunvariabler } \\
\hline \multicolumn{2}{|l|}{ Karlstad } & & 31,9 \\
\hline \multicolumn{2}{|c|}{ Norrköping } & & 28,5 \\
\hline \multicolumn{2}{|c|}{ Upplands Väsby } & & 26,2 \\
\hline \multicolumn{2}{|c|}{ Östhammar } & & 13,4 \\
\hline
\end{tabular}

\section{Tabell 2}

terna om försörjningshinder bygger alltså på socialarbetarnas uppfattning. Dessa uppgifter ingår i regel i utredningen i socialbidragsärenden, varför vi kan anta att socialarbetarna har rätt information. När det gäller uppgifter om ohälsa och missbruk är risken troligtvis större att socialarbetarna underrapporterar än tvärtom, eftersom mer djupgående utredningar av individuella förutsättningar att bli självförsörjande förefaller ovanliga (se t.ex. socialtjänstinspektörernas granskningar av ekonomiskt bistånd i Stockholms stad). Försörjningshindret bristande arbetsmotivation bedöms möjligen mer godtyckligt än andra försörjningshinder.

Jenny Nybom:Vilket resultat har socialtjänstens aktivering av socialbidragstagare? 
Kommunerna är inkluderade $\mathrm{i}$ analysen för att kontrollera för inflytandet från strukturella skillnader, till exempel arbetslöshet.

\section{Registeruppföljning av arbete och socialbidrag}

Klienternas försörjning följdes upp via registeruppgifter om inkomster under 2004 och 2005 som hämtats från SCB:s individdatabas LISA (longitudinell integrationsdatabas för sjukförsäkrings- och arbetsmarknadsstudier). Registeruppföljningen har prövats och godkänts av den regionala etikprövningsnämnden i Stockholm.

Utfallsmåtten arbete och socialbidrag bygger på variablerna deklarerad lön från arbete och inkomst från socialbidrag (individualiserat från familjen/hushållet). Klienter som hade inkomster motsvarande två basbelopp från lön eller socialbidrag för åren 2004 och 2005 ingår i respektive utfall ${ }^{3}$. Utfallen baseras på två års varaktighet för att fånga samband med att klienter "fastnar" i socialbidragstagande respektive "får fäste" på arbetsmarknaden och för att inte missa eventuella samband med resursaktivering, som enligt tidigare forskning kan väntas ge fördröjda resultat jämfört med jobbaktivering (Greenberg et al. 2004).

Enligt den forskning som redovisats tidigare är det relativt få av samtliga socialbidragstagare, omkring 20 procent,

3 De aktuella basbeloppen var 39300 kronor år 2004 och 39400 kronor år 2005. som får arbete enligt gängse definition av kärnarbetskraft, det vill säga inkomster på 3,5 basbelopp under ett år (Bergmark \& Bäckman 2007). Om 3,5 basbelopp hade tillämpats som definition på arbete hade omkring 10 procent av klienterna i datamaterialet haft utfallet arbete. Det kan bero på att klienter med tillfälligt behov har uteslutits ur urvalet. Personer som får arbete är jämförelsevis fler i denna grupp. Eftersom sambandsanalyser med få personer i utfallet ger osäkra skattningar, bestämdes gränsen till 2 basbelopp. Det är av intresse om aktivering kan innebära att personer får en varaktig löneinkomst, även om de inte inträder i den så kallade kärnarbetskraften.

I registeruttaget ingick uppgifter om antal dagar som klienten varit i arbetsmarknadssysselsättning. De klienter som hade erhållit deklarerad lön som huvudinkomst, och samtidigt haft motsvarande omfattning i åtgärdssysselsättning, antas ha haft lönebidrag och har uteslutits från gruppen med utfallet arbete. För att få lönebidrag måste Arbetsförmedlingen göra bedömningen att personens arbetsförmåga är helt nedsatt för lång tid framöver.

\section{Analyser}

Sambanden mellan aktiveringsvariablerna och arbete respektive socialbidrag undersöks med logistiska regressionsanalyser. Logistiska regressioner används när utfallsmåtten är lämpliga att dikotomisera. Valet att dikotomisera utfallen avspeglar syftet att undersöka 
om aktivering och sanktioner alls har något samband med arbete respektive socialbidrag. Om forskningsfrågan hade handlat om hur aktivering och sanktioner är kopplade till förändringar i omfattning på inkomst från arbete och socialbidrag, hade en linjär regression varit motiverad.

I logistiska regressioner redovisas skattningarna - regressionskoefficienterna - i form av oddskvoter. En oddskvot visar hur oddset att få ett aktuellt utfall är kopplat till att tillhöra en viss kategori jämfört med att inte tillhöra den eller jämfört med att tillhöra en referenskategori. Oddskvoter är inte detsamma som sannolikheter; i regel är värdet på oddskvoterna något högre än risken eller chansen för den aktuella händelsen. För läsbarhetens skull benämns oddskvoterna ibland som sannolikheter.

Inledningsvis görs två regressionsanalyser som undersöker samband mellan utfallen (arbete respektive socialbidrag) och jobbaktivering, resursaktivering samt sanktioner. Därefter undersöker två regressionsanalyser samband mellan utfallen och de aktiveringskombinationer som innehåller aktiveringsinsats och/eller sanktion jämfört med Ingen aktivering, den vanligast förekommande "insatsen" för klienterna.

För att ytterligare utforska sambanden genomförs ytterligare fem regressionsanalyser för arbete och fem för socialbidrag, där varje aktiveringskombination $\mathrm{i}$ tur och ordning får utgöra referens till de övriga. Dessa skattningar blir ännu mer osäkra (bredare konfidensintervall) än de tidigare eftersom referenskategorierna innehåller färre personer än när variabeln
Ingen insats är referenskategori. Jämförelser med insatsen Ingen insats redovisas inte i dessa resultat då de tidigare regressionerna undersökt detta.

En källa till osäkerhet i regressionsanalyser är om de oberoende variablerna är högt korrelerade med varandra, s.k. multikollinearitet. Detta har undersökts och de oberoende variablerna i materialet är inte högt korrelerade. De högsta korrelationerna erhölls mellan hushållsvariabeln och övriga karaktäristika, vilket indikerar att inflytande från hushåll kan vara svårt att separera från inflytande från andra variabler.

Klientvariabler och kommuner är inkluderade i analyserna som kontrollvariabler men oddskvoterna för dessa redovisas inte i resultaten; analys av dessa samband faller utanför syftet med artikeln.

\section{Resultat}

Omkring en fjärdedel (24 procent) av klienterna har utfallet arbete och en knapp femtedel (17 procent) har utfallet socialbidrag. Det betyder att en stor grupp av klienterna har blandade inkomster bestående av exempelvis socialbidrag, sjukpenning, timanställningar och kanske lån och stöd från närstående.

\section{Aktiveringsinsatser och sanktioner}

I tabell 3 redovisas de två logistiska regressioner som undersöker sambandet mellan aktiveringsinsatser och arbete respektive 


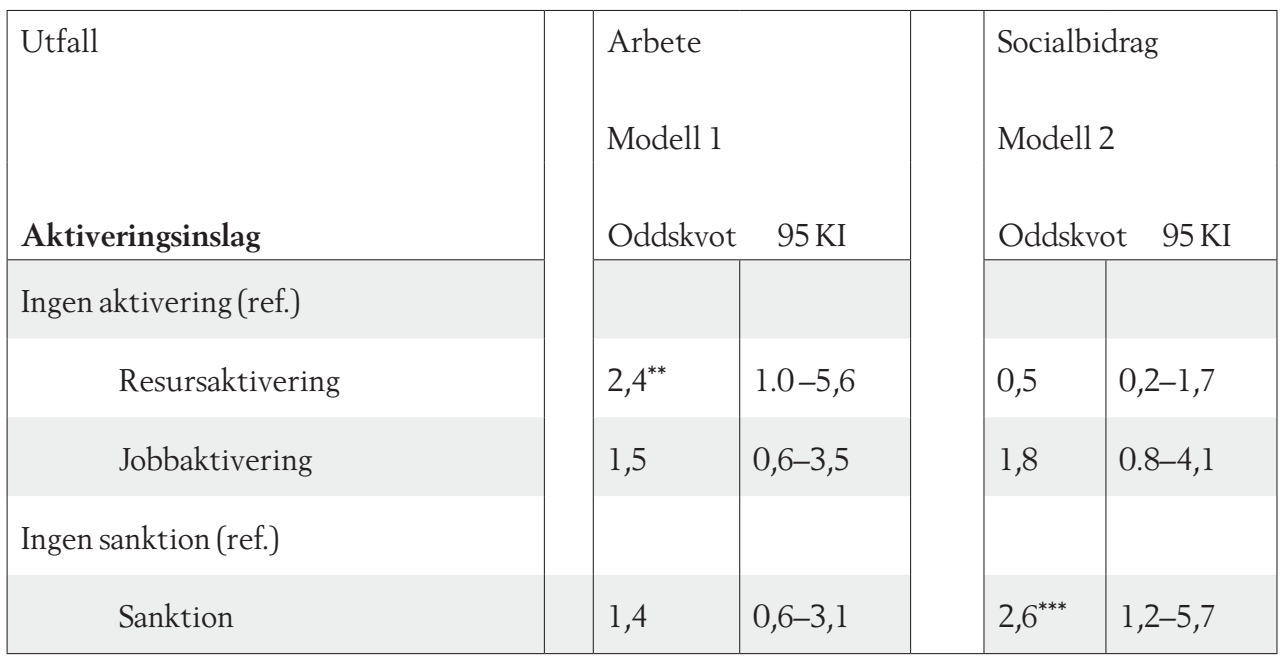

Tabell 3

socialbidrag och sambandet mellan sanktioner och arbete respektive socialbidrag. Som framgår finns det ett signifikant positivt samband mellan Resursaktivering och arbete. Resursaktivering har en negativ icke-signifikant ${ }^{4}$ koefficient i analysen av socialbidrag, vilket indikerar att det har ett entydigt inflytande på klienternas försörjning.

Sanktioner har ett signifikant positivt samband med socialbidrag. Sanktioner har också en positiv, men icke-signifikant koefficient $\mathrm{i}$ analysen av arbete, vilket indikerar ett mindre entydigt samband med försörjning.

$4 \quad$ Ej signifikanta samband visas då det kan finnas ett värde i ackumulerad kunskap om riktningen i en variabels inflytande på en annan variabel över tid och urval, även när inflytandet inte är signifikant som en följd av exempelvis små urval eller ovanliga utfall. Om riktningen på inflytandet är konsistent bildar det en god utgångspunkt för antaganden i vidare forskning (se t.ex. Falk \& Greenbaum 1995; Hosmer \& Lemeshow 1989).

\section{Tabell 3.}

Logistiska regressionsanalyser. Samband mellan aktiveringsinsatser och sanktioner där Ingen insats utgör referenskategori (ref.). Oddskvoter $(n=351)$.

${ }^{*} \mathrm{p}<0,1 ;{ }^{* *} \mathrm{p}<0,05 ;{ }^{* * *} \mathrm{p}<0,01$

I analyserna kontrolleras för klient- och kommunvariabler.

För att undersöka hur känsliga de skattade sambanden är för operationaliseringarna av arbete och socialbidrag skattades alternativa modeller.

För utfallet arbete skattades modeller med 2,5, 3 respektive 3,5 basbelopp (visas ej i tabell). I samtliga modeller kvarstod det positiva sambandet mellan Resursaktivering och arbete. Sambandet var inte signifikant i modellen med 3 basbelopp men i de övriga två.

För utfallet socialbidrag skattades en ny modell, där kriteriet var att socialbidrag utgjorde individens största inkomst- 


\begin{tabular}{|c|c|c|c|c|}
\hline $\begin{array}{l}\text { Utfall } \\
\text { Aktiveringskombinationer }\end{array}$ & \multicolumn{2}{|c|}{$\begin{array}{l}\text { Arbete } \\
\text { Modell } 1 \\
\text { Oddskvot } 95 \mathrm{KI}\end{array}$} & \multicolumn{2}{|c|}{$\begin{array}{l}\text { Socialbidrag } \\
\text { Modell } 2 \\
\text { Oddskvot } 95 \mathrm{KI}\end{array}$} \\
\hline \multicolumn{5}{|l|}{ Ingen aktivering (ref.) } \\
\hline Jobbaktivering och ingen sanktion & 2,2 & $0,8-5,8$ & 1,3 & $0,5-3,7$ \\
\hline Jobbaktivering och sanktion & 0,9 & $0,2-4,7$ & $6,1^{* * *}$ & $1,8-21,2$ \\
\hline Resursaktivering och ingen sanktion & 1,9 & $0,7-5,3$ & 0,5 & $0,1-2,4$ \\
\hline Resursaktivering och sanktion & $5,1^{* *}$ & $1,3-19,7$ & 1,3 & $0,2-7,3$ \\
\hline Sanktion och ingen aktivering & 1,7 & $0,6-4,9$ & 1,9 & $0,7-5,0$ \\
\hline
\end{tabular}

Tabell 4

källa oavsett storlek på socialbidragsinkomsten, vilket innebar att fler personer hade utfallet socialbidrag. I denna modell kvarstod ett signifikant positivt samband mellan Sanktion och socialbidrag 5 .

Aktiveringskombinationer jämfört med ingen aktivering

I tabell 4 redovisas de två logistiska regressioner som undersöker sambandet mellan

5 För att ytterligare granska skattningarnas känslighet har frågan om icke observerad heterogenitet beaktats. I en logistisk regression antar beräkningarna konstant icke observerad heterogenitet mellan grupper och tidpunkter, vilket inte nödvändigtvis är uppfyllt (Mood 2010). Vid tillämpning med linjär regression (där den icke observerade heterogeniteten tillåts variera) på samtliga skattade modeller kvarstår koefficienternas tecken och inbördes relation, vilket tyder på att icke observerad heterogenitet inte har avgörande inflytande på skattningarna. olika aktiveringskombinationer jämfört med Ingen insats för arbete respektive socialbidrag.

\section{Tabell 4.}

Logistiska regressionsanalyser. Samband mellan kombinationer av aktiveringsinsatser och sanktioner där Ingen insats utgör referenskategori (ref.). Oddskvoter ( $\mathrm{n}=$ 351).

${ }^{*} \mathrm{p}<0,1 ;{ }^{* *} \mathrm{p}<0,05 ;^{* * *} \mathrm{p}<0,01$

I analyserna kontrolleras för klient- och kommunvariabler.

Endast en aktiveringskombination, Resursaktivering och sanktion, har ett signifikant positivt samband med utfallet arbete. Det breda konfidensintervallet visar att skattningen är osäker. Övriga aktiveringskombinationer har positiva koefficienter, med undantag för Jobbak- 


\begin{tabular}{|c|c|c|c|c|c|c|c|}
\hline \multirow[t]{2}{*}{ Utfall } & \multicolumn{2}{|c|}{$\begin{array}{l}\text { Arbete } \\
\text { Modell 1 }\end{array}$} & \multicolumn{2}{|c|}{$\begin{array}{l}\text { Arbete } \\
\text { Modell } 2\end{array}$} & $\begin{array}{l}\text { Arbete } \\
\text { Modell } 3\end{array}$ & \begin{tabular}{|l|} 
Arbete \\
Modell 4
\end{tabular} & $\begin{array}{l}\text { Arbete } \\
\text { Modell } 5\end{array}$ \\
\hline & $\begin{array}{l}\text { Odc } \\
95 \mathrm{~K}\end{array}$ & & $\begin{array}{l}\mathrm{Od} \\
\mathrm{KI}\end{array}$ & vot 95 & $\begin{array}{l}\text { Oddskvot } \\
95 \mathrm{KI}\end{array}$ & $\begin{array}{l}\text { Oddskvot } \\
95 \mathrm{KI}\end{array}$ & $\begin{array}{l}\text { Oddskvot } \\
95 \mathrm{KI}\end{array}$ \\
\hline $\begin{array}{l}\text { Aktiveringskombina- } \\
\text { tioner }\end{array}$ & $\begin{array}{l}\text { Jobl } \\
\text { ing } \\
\text { sank }\end{array}$ & $\begin{array}{l}\text { aktiver- } \\
\text { ch ingen } \\
\text { tion (ref.) }\end{array}$ & $\begin{array}{l}\text { Jobb } \\
\text { och s } \\
\text { (ref.) }\end{array}$ & $\begin{array}{l}\text { aktivering } \\
\text { anktion }\end{array}$ & $\begin{array}{l}\text { Resursak- } \\
\text { tivering och } \\
\text { ingen sank- } \\
\text { tion (ref.) }\end{array}$ & $\begin{array}{l}\text { Resursak- } \\
\text { tivering och } \\
\text { sanktion } \\
\text { (ref.) }\end{array}$ & $\begin{array}{l}\text { Sanktion och } \\
\text { ingen aktiver- } \\
\text { ing (ref.) }\end{array}$ \\
\hline $\begin{array}{l}\text { Jobbaktivering och } \\
\text { ingen sanktion }\end{array}$ & & (ref.) & 2,4 & $0,4-14,2$ & $1,1 \quad 0,3-4,2$ & $0,4 \quad 0,9-2,0$ & $1,3 \quad 0,4-4,6$ \\
\hline $\begin{array}{l}\text { Jobbaktivering och } \\
\text { sanktion }\end{array}$ & & $0,1-2,4$ & 1 & (ref.) & $0,5 \quad 0,1-3,0$ & $0,2^{*} \quad 0,3-1,3$ & $0,5 \quad 0,9-3,3$ \\
\hline $\begin{array}{l}\text { Resursaktivering och } \\
\text { ingen sanktion }\end{array}$ & 0,9 & $0,2-3,2$ & 2,1 & $0,3-13,5$ & $1 \quad$ (ref.) & $0,4 \quad 0,8-1,8$ & $1,1 \quad 0,3-4,3$ \\
\hline $\begin{array}{l}\text { Resursaktivering och } \\
\text { sanktion }\end{array}$ & 2,3 & $0,5-10,8$ & $5,6^{*}$ & $0,8-40,5$ & $2,7 \quad 0,6-12,7$ & (ref.) & $3,0 \quad 0,6-14,2$ \\
\hline $\begin{array}{l}\text { Sanktion och ingen } \\
\text { aktivering }\end{array}$ & 0,8 & $0,2-2,8$ & 1,9 & $0,3-11,7$ & $0,9 \quad 0,2-3,5$ & $0,3 \quad 0,1-1,6$ & (ref.) \\
\hline
\end{tabular}

Tabell 5

tivering och sanktion, som har ett svagt negativt inflytande på arbete.

Jobbaktivering och sanktion har ett signifikant positivt samband med socialbidrag. Sanktion och ingen aktivering har en positiv koefficient och Resursaktivering och ingen sanktion en negativ. Resursaktivering och sanktion och Jobbaktivering och ingen sanktion förefaller ha obetydligt inflytande.

För dessa två regressionsanalyser har också modeller med de alternativa operationaliseringarna som beskrivits ovan genomförts. Sambanden kvarstod också här (visas ej i tabell).

\section{Aktiveringskombinationer jämfört med varandra}

I tabell 5 presenteras resultaten från fem regressionsanalyser av utfallet arbete. De fem kombinationerna av aktiveringsinsat- ser och sanktioner har omväxlande utgjort referenskategori. De signifikanta samband som framträder när vi jämför aktiveringskombinationer med varandra går i linje med tidigare resultat. Att få arbete har ett positivt samband med Resursaktivering och sanktion jämfört med Jobbaktivering och ingen sanktion och ett negativt samband med Jobbaktivering och sanktion jämfört med Resursaktivering och sanktion.

\section{Tabell5.}

Logistiska regressionsanalyser där aktiveringskombinationen som utgör referenskategori (ref.) varierar. Oddskvoter, $\mathrm{n}$ $=351$.

${ }^{*} \mathrm{p}<0,1 ;{ }^{* *} \mathrm{p}<0,05 ;{ }^{* * *} \mathrm{p}<0,01$

I analyserna kontrolleras för klient- och kommunvariabler. 


\begin{tabular}{|c|c|c|c|c|c|c|c|c|}
\hline Utfall & $\begin{array}{l}\text { Socia } \\
\text { Mod } \\
\text { Odds } \\
95 \mathrm{KI} \\
\end{array}$ & $\begin{array}{l}\text { lbidrag } \\
\text { ell } 1 \\
\text { kvot }\end{array}$ & \begin{tabular}{|l} 
Social \\
Mode \\
Odds \\
$95 \mathrm{KI}$ \\
\end{tabular} & $\begin{array}{l}\text { drag } \\
2 \\
\text { ot }\end{array}$ & $\begin{array}{l}\text { Socialb } \\
\text { Modell } \\
\text { Oddskv } \\
95 \mathrm{KI} \\
\end{array}$ & $\begin{array}{l}\text { idrag } \\
3 \\
\text { vot }\end{array}$ & $\begin{array}{l}\text { Socialbidrag } \\
\text { Modell } 4 \\
\text { Oddskvot } \\
95 \mathrm{KI} \\
\end{array}$ & $\begin{array}{l}\text { Socialbidrag } \\
\text { Modell } 5 \\
\text { Oddskvot } \\
95 \mathrm{KI}\end{array}$ \\
\hline $\begin{array}{l}\text { Aktiveringskombi- } \\
\text { nationer }\end{array}$ & $\begin{array}{l}\text { Jobbe } \\
\text { ing o } \\
\text { sankt }\end{array}$ & $\begin{array}{l}\text { ktiver- } \\
\text { ch ingen } \\
\text { ion (ref.) }\end{array}$ & $\begin{array}{l}\text { Jobba } \\
\text { och sa } \\
\text { (ref.) }\end{array}$ & $\begin{array}{l}\text { vering } \\
\text { tion }\end{array}$ & $\begin{array}{l}\text { Resursa } \\
\text { ing och } \\
\text { sanktio } \\
\end{array}$ & $\begin{array}{l}\text { aktiver- } \\
\text { ingen } \\
\text { n (ref.) }\end{array}$ & $\begin{array}{l}\text { Resursak- } \\
\text { tivering och } \\
\text { sanktion (ref.) } \\
\end{array}$ & $\begin{array}{l}\text { Sanktion och } \\
\text { ingen aktiver- } \\
\text { ing (ref.) }\end{array}$ \\
\hline $\begin{array}{l}\text { Jobbaktivering och } \\
\text { ingen sanktion }\end{array}$ & 1 & (ref) & $02^{* *}$ & $0,6-0,9$ & 2,7 & $0,4-15,8$ & $0,1-6,9$ & $0,6 \quad 0,2-2,4$ \\
\hline $\begin{array}{l}\text { Jobbaktivering och } \\
\text { sanktion }\end{array}$ & $4,7^{* *}$ & $1,2-18,3$ & 1 & $r e f)$ & $12,4^{* * *}$ & $1,9-81,6$ & $4,7 \quad 0,7-33,2$ & $3,1 \quad 0,8-12,5$ \\
\hline $\begin{array}{l}\text { Resursaktivering } \\
\text { och ingen sanktion }\end{array}$ & 0,4 & $0,1-2,2$ & $0,1^{* * *}$ & $0-0,5$ & 1 & (ref.) & $0,4 \quad 0-3,4$ & $0,3 \quad 0,4-1,5$ \\
\hline $\begin{array}{l}\text { Resursaktivering } \\
\text { och sanktion }\end{array}$ & 1,0 & $, 1-6,7$ & 0,2 & $-1,5$ & 2,6 & $3-24$ & $1 \quad$ (ref.) & $0,6 \quad 0,1-4,2$ \\
\hline $\begin{array}{l}\text { Sanktion och inge } \\
\text { aktivering }\end{array}$ & 1,5 & $0,4-5,3$ & 0,3 & $0,1-1,3$ & 4,0 & $0,7-23,4$ & $1,5 \quad 0,2-9,5$ & $1 \quad$ (ref.) \\
\hline
\end{tabular}

Tabell 6

De icke-signifikanta sambanden går i förväntad riktning. Resursaktivering och sanktion har en positiv koefficient jämfört med alla andra kombinationer och Jobbaktivering och sanktion en negativ koefficient jämfört med alla andra kombinationer. Samtliga kombinationer har en positiv koefficient när de jämförs med Jobbaktivering och sanktion.

I tabell 6 visas resultaten från fem regressionsanalyser av utfallet socialbidrag. De signifikanta sambanden visar att Jobbaktivering och sanktion är positivt kopplat till socialbidrag jämfört med tre av de andra insatserna, Resursaktivering och sanktion, Resursaktivering och ingen sanktion och Jobbaktivering och ingen sanktion.

\section{Tabell6.}

Logistiska regressionsanalyser där aktiveringskombinationen som utgör referenskategori (ref.) varierar. Oddskvoter $(n=351)$.
${ }^{*} \mathrm{p}<0,1 ;{ }^{* *} \mathrm{p}<0,05 ;{ }^{* * *} \mathrm{p}<0,01$

I analyserna kontrolleras för klient- och kommunvariabler.

Jobbaktivering och ingen sanktion har en negativ koefficient jämfört med Jobbaktivering och sanktion och jämfört med Resursaktivering och sanktion. Sanktioner verkar vara negativt om man vill undvika socialbidrag, oavsett med vilken aktiveringsinsats det kombineras. Detsamma tycks inte vara fallet när det gäller arbete.

Sammantaget framstår Jobbaktivering och sanktion som en entydigt negativ aktiveringskombination om arbete eftersträvas och socialbidrag inte eftersträvas.

\section{Diskussion}

Syftet med den här studien har varit att undersöka hur aktiveringsinsatser och sanktioner är kopplade till om socialbidragstagare kommer i arbete eller fort- 
sätter att ha socialbidrag. Studiens data samlades in under åren 2003-2005. Resultatens generaliserbarhet begränsas av materialets omfattning: $i$ analyserna ingår 351 klienter från fyra kommuner.

De politiska förhoppningarna på socialtjänstens möjligheter att hjälpa socialbidragstagare till arbete med aktivering är tydliga. Utifrån fattigvårdens historia kan vi betrakta aktiveringspolitikens och aktiveringens två huvudinslag, aktiveringsinsatser och sanktioner, som uttryck för stöd och kontroll. I de politiska initiativen förefaller kontrollinslaget spela huvudrollen. Ett exempel på det är jobbtorgen som infördes i stor skala i Stockholms stad år 2008, med en generell inriktning mot förstärkta krav på arbetssökande för arbetslösa socialbidragstagare (se t.ex. Dahlberg, Johansson \& Mörk 2008). Ett annat exempel är den senaste ändringen av socialtjänstlagen som utvidgar socialtjänstens mandat att ställa krav på aktiveringsinsatser och ge sanktioner, till att omfatta alla bidragstagare oavsett ålder. Med tanke på frågans aktualitet och den begränsade kunskapen på området utgör studien, trots sina svagheter, ett relevant kunskapsbidrag. Materialets begränsade storlek innebär dock att redovisade samband främst kan användas som utgångspunkt för vidare forskning.

Enligt analyserna är det bättre att ge en bidragstagare Resursaktivering än Jobbaktivering, enbart Sanktioner eller ingenting alls om dennas chanser till arbete ska öka. Detta samband har stöd i bland annat Giertz forskningssammanställning (SOU 2007:2), som visade att arbetspraktik på reguljär arbetsplats fungerade bättre än jobbträning för att hjälpa bidragstagare till arbete, och i forskning som visar på betydelsen av utbildning för etablering på arbetsmarknaden (se t.ex. Bäckman 2011; Bäckman \& Nilsson 2011). Över hälften av klienterna i den här studien saknade, enligt socialarbetarna, resurser i form av utbildning eller arbetserfarenhet. Trots det fick bara 10 procent resursaktivering. $\mathrm{Om}$ en person som får resursaktivering uteblir från sin utbildning eller praktik verkar en sanktion (som gäller en del av socialbidraget) kunna förstärka möjligheterna till arbete.

Om socialtjänsten vill minska sannolikheten för fortsatt socialbidragstagande ska Sanktioner och kombinationen Jobbaktivering och sanktion undvikas i arbetet med bidragstagarna. Jobbaktivering utan sanktion minskade risken att fortsätta ha socialbidrag jämfört med Jobbaktivering och sanktion. Sambandens olika riktning när det gäller sanktioner går i linje med tidigare forskning som visar att sanktioner och obligatoriska aktiveringsprogram kan ha negativa effekter för personer som står långt ifrån arbetsmarknaden men positiva effekter för personer som befinner sig nära arbetsmarknaden (se t.ex. Pavetti, Derr \& Hesketh 2003; Cherlin et al. 2002; van der Berg et al. 2004; Malmberg-Heimonen 2005; Smedslund et al. 2006; Peck 2007).

Vetskapen om selektionseffekter till aktiveringsinsatser och sanktioner innebär att vi inte kan dra slutsatsen att Sanktioner eller Jobbaktivering och sanktion i sig är orsaken till att personer fortsätter ha socialbidrag. Vi kan inte heller påstå att orsaken till att vissa klienter fått arbete 
är att de deltagit i Resursaktivering eller fått Resursaktivering och sanktion. I den här studien har vi kunnat kontrollera för relativt många selektionseffekter tack vare uppgifter om klienternas karaktäristika och försörjningshinder, men trots det finns det med stor sannolikhet även ickeobserverbara selektionseffekter som inte fångats in. Det är dessutom svårt att veta i vilken utsträckning socialarbetarna har rätt i sin uppfattning om sina klienters försörjningshinder.

Utifrån tidigare forskning, som visar att sanktioner ofta riktas till gruppen som står längst från arbetsmarknaden, ligger det nära till hands att dra slutsatsen att personer som har goda utsikter till arbete får resursaktivering och att personer som har sämre utsikter på arbetsmarknaden får jobbaktivering, samtidigt som det inom båda dessa grupper finns personer som tilldelas sanktioner.

En möjlig tolkning är också att effekten av sanktioner är avhängig innehållet $i$ de aktiveringsinsatser som de kombineras med, och inte bara sammanhänger med hur långt ifrån arbetsmarknaden klien- ten befinner sig. Kanske kommunicerar sanktioner, som används i samband med en aktiveringsinsats som stärker klientens resurser (resursaktivering), ett slags allvar i avsikten med aktiveringsinsatsen och förändringsarbetet. Sanktioner som används i samband med jobbaktivering, den aktivering som ofta i forskningen jämförs med traditionell fattigvård med en avskräckande funktion, kanske snarare kommunicerar ett ifrågasättande av arbetsmotivationen och indirekt av klientens behov av och rätt till bidrag.

Materialets begränsningar gör det vanskligt att dra de långtgående slutsatser som tas upp här. Det krävs mer forskning om kopplingen mellan aktivering och utfallet för klienterna. Resultaten pekar på att kombinationer av olika inslag i aktivering är av intresse för vidare studier.

I avvaktan på mer kunskap kanske socialbidragstagarna skulle gynnas av att socialtjänst och politiker funderar på om innehållet i aktiveringsinsatser och användningen av aktiveringsinsatser och sanktioner sker utifrån den kunskap som trots allt finns idag. 


\section{Referenser}

Angelin, A. (2009). Den dubbla vanmaktens logik. En studie om långvarig arbetslöshet och socialbidrag bland unga vuxna. Doktorsavhandling. Lunds universitet, Socialhögskolan.

Bergmark, Å. (1991). Socialbidrag och försörjning. En studie av bidragstagande bland ensamstående män utan barn. Doktorsavhandling. Stockholms universitet, Institutionen för socialt arbete.

Bergmark, Å. (2000). Med vilken måttstock? Om valet av kriterier vid utvärderingar av arbete med socialbidrag. I Puide, A. (red.) Socialbidrag i forskning och praktik. Stockholm: Gothia.

Bergmark, Å. \& Bäckman, O. (2004). Stuck with Welfare? Long-term Social Assistance Recipiency in Sweden. European Sociological Review, 20, 425-443.

Bergmark, Å. \& Bäckman, O. (2007). Socialbidragstagandets dynamik - varaktighet och utträden från socialbidragstagande under 2000-talet. Socialvetenskaplig tidskrift, 14, 134-152.

Bergmark, Å. \& Bäckman, O. (2011). Vad händer med socialbidragstagarna? I S. Alm, O. Bäckman, A. Gavanas \& A. Nilsson (red.) Utanförskap (53-78). Stockholm: Dialogos förlag. Institutet för framtidsstudier.

Bergmark, A. \& Palme, J. (2003). Welfare and the unemployment crisis: Sweden in the 1990s. International Journal of Social Welfare, 12(2), 108-122.

Brännström, L. \& Stenberg, S.-Å. (2007). Does social assistance recipiency influence unemployment? Macro-level findings from Sweden in a period of turbulence. Acta Sociologica, 50(4),349-364.

Boll, J. \& Christensen, T. Q. (2002). Kontanthjoelpsmottagare og arbejdsmarket. Casestudie fra Vestengen. København. Socialforskningsinstitutet (Rapport Socialforskningsinstitutet 2002:1).

Cherlin, A. J., Bogen, K., Quane, J, M \& Burton L.
(2002). Operating within the rules: welfare recipients experience with sanction and case closings. Social Service Review, (September 2002), 387-405.

Bäckman, O. (2011). Att få fotfäste på arbetsmarknaden. I S. Alm, O. Bäckman, A. Gavanas \& A. Nilsson (red.), Utanförskap (81-103). Stockholm:Dialogos förlag.

Bäckman, O. \& Nilsson, A. (2011). “Ung och utanför". I S. Alm, O. Bäckman, A. Gavanas \& A. Nilsson (red.), Utanförskap (163-186). Stockholm:Dialogos Förlag.

Dahl, E. (2003). Does 'workfare' work? The Norweigan experience. International Journal of Social Welfare, 12, 274-28.

Dahlberg, M., Johansson, K., Mörk, E. (2008). Effekter av aktiveringskrav på socialbidragstagare i Stockholms stadsdelar. Uppsala: IFAUinstitutet för arbetsmarknadspolitisk utvärdering (IFAU-Rapport 2008:24).

Eardly, T., Bradshaw, J., Ditch, J., Gough, I. and Whiteford, P. (1996). Social assistance schemes in OECD countries: Vol. 1, synthesis report. DSS Research Report 46,London: HMSO.

Ekström, V. (2005). Individens eget ansvar och samhällets stöd. En utvärdering av "Skärholmsmodellen" vid Jobbcentrum Sydväst. Stockholm: FoU-enheten Stockholms stad (FoU-rapport 2005:10).

Falk, R. \& Greenbaum, C. W. (1995). Significance tests die hard: The amazing persistence of a probabilistic misconception. Theory and Psychology, 5(1), 75-98.

Franzén, E. M. (2002). I välfärdsstatens väntrum studier om invandrares socialbidragstagande. Doktorsavhandling. Göteborgs universitet. Institutionen för socialt arbete.

Fridberg,T.(1993). Langvarig socialhjelp i Norden. København: Socialforskningsinstitutet (Socialforskningsinstitutet. Rapport 93:10).

Furåker, B. (1997). Arbetslinjen, socialbidraget och massarbetslöshet. I: Socialstyrelsen. 11 röster 
om socialbidrag. Socialstyrelsen (SoS-rapport 1997:5).

Geldof, D. (1999). 'New Activation Policies: Promises and Risks'. In:Heikkilä, M. (red.) Linking welfare and work. Dublin: European Foundation for the Improvement of Living and Working Conditions, 13-25.

Giertz, A. (2004). Making the poor work. Social Assistance and Activation Programmes in Sweden. Doktorsavhandling. Lunds universitet. Socialhögskolan.

Greenberg, D., Ashworth, K., Cebulla, A. \& Walker. R. (2004). Do welfare-to-Work Programmes Work for Long? Fiscal Studies, 25 (1), $27-53$.

Gunnarsson, E. (1993). I välfärdsstatens utmarker. Om socialbidrag och försörjning bland ensamstående kvinnor utan barn. Doktorsavhandling. Stockholms universitet, Institutionen för socialt arbete.

Gustafsson, B. (1984). En bok om fattigdom. Lund: Studentlitteratur.

Halleröd, B. (2003). "Varför får folk socialbidrag? Analys av socialbidragstagandets bestämningsfaktorer", Socialvetenskaplig tidskrift, (2-3), 238-66.

Halvorssen, R. \& Jensen, P. (2004). "Activation in Scandinavian Welfare Policy. Denmark and Norway in a comparative perspective", European Societies, 6 (4), 461-483.

Hanesch, W. (1999). The debate on reforms of social assistance in Western Europe. In: Heikkila, M (red). Linking Welfare and Work. Dublin: European Foundation for the Improvement of Living and Working Conditions, 71-77.

Hasenfeld, Y., Ghose, T \& Larson, K. (2004). The logic of sanctioning Welfare recipients: an empirical assessment. Social Service Review (June 2004), 304-319.

Hedblom, A. (2004). Aktiveringspolitikens janusansikte. En studie av differentiering, inklusion och marginalisering. Doktorsavhandling. Lunds universitet: Socialhögskolan.

Heikkilä, M. (red.) (1999). Linking welfare and work. Dublin: European Foundation for the Improvement of Living and Working Condi- tions, 13-25.

Heikkilä, M. \& Keskitalo, E. (red.) (2001) Social Assistance in Europe. A comparative study on minimum income in seven European countries. Helsinki: Stakes. National research and development centre for Welfare and Health.

Hjertner Thorén, K. (2005). Kommunal aktiveringspolitik: en fallstudie av det praktiska arbetet med arbetslösa socialbidragstagare. Uppsala: IFAU-institutet för arbetsmarknadspolitisk utvärdering (IFAU-Rapport 2005:11).

Hosmer, D. W. \& Lemeshow, S. (1989). Applied logistic regression. New York: Wiley.

Hvinden, B. (1999). Activation: a Nordic Perspective. In: M. Heikkila., ed., Linking Welfare and Work, Dublin: European Foundation for the Improvement of Living and Working Conditions, 27-40.

Johansson, H. (2001). I det sociala medborgarskapets skugga. Rätten till socialbidrag under 1980- och 1990-talen. Doktorsavhandling. Lunds universitet, Socialhögskolan.

Jonasson, I. (1989). När man lyckas... - men ändå misslyckas. Slutrapport från ett arbetslöshetsprojekt. Stockholm: Forsknings- och utvecklingsbyrån/Socialdistrikt 14 (FoU-rapport nr 117).

Jonasson, I. (1996). Långuariga socialbidragstagare. Doktorsavhandling. Lic.-avh. Stockholms universitet, Institutet för socialt arbete.

Jonsson, M. (2001). Och metoderna kommer och går. Intervjuer med handläggare och arbetslösa inom socialtjänsten. Stockholm: FoU-Södertörn (FoU-Södertörn Skriftserie, Nr 14/01).

Junestav, M. (2004). Arbetslinjer i svensk socialpolitisk debatt och lagstiftning 1930-2001. Doktorsavhandling. Uppsala universitet, Ekonomisk-historiska institutionen.

Jönsson, L. R. \& Starrin, B. (1999). I socialt underläge. En explorativ studie av arbetslösa socialbidragssökande. Stockholm: Socialhögskolan.

Karlsson, L. (2006). Gilla grått - riskfaktor social bidrag eller stöd till försörjning. Öland: Fokus i Kalmar län (Fokus-Rapport 2006:2).

Korpi, W. (1971). Fattigdom i välfàrden. Stockholm: Tidens förlag.

Lindqvist, R. \& Marklund, S. (1995). Forced to

Jenny Nybom:Vilket resultat har socialtjänstens aktivering av socialbidragstagare? 
work and deliberated from work. A historical perspective on work and welfare in Sweden. Scandinavian Journal of Social Welfare, 4, 224 237.

Lødemel, I. \& Schulte, B. (1992). Social Assistance: a part of social security or the Poor Law in new disguise? Leuven: European Institute of Social Security.

Lødemel, I. (1997). Pisken i arbeidslinja. Om iverksetjinga av arbeid for sosialhjelp. Oslo: Forskningsstiftelsen Fafo (Fafo-rapport 226).

Lødemel, I. \& Trickey, H. (red.) (2001). An offer you can't refuse. Workfare in an international perspective. Southampton: The Policy Press.

Lødemel, I. (ed.) (2002). Workfare in six European countries: findings from evaluations and recommendations for future development. Oslo: Forskningsstiftelsen Fafo (Fafo-rapport 2002:24).

Lødemel, I., Johannessen, A., Buschmann, E., Nilsen, K., L. and Velvin, G. (2004). Nytter det? Erfaringer fra Tiltaksforsøket 2000-2004. Oslo: Høgskolen i Oslo.

Malmberg-Heimonen,I.(2005). Public welfare policies and private responses: studies of European labour market policies in transition. Doktorsavhandling. Helsingfors: Finnish Institute of Occupational Health.

Milton, P. \& Bergström, R. (1998). Uppsalamodellen och socialbidragstagarna. En effektutvärdering. Stockholm: Socialstyrelsen (Cusskrift 1998:1).

Mood, C. (2010). Logistic regression: Why we cannot do what we think we can do and what we can do about it. European Sociological Review, 26(1), s. 67-82.

Nordenmark, M. (1999). Arbetslöshet, arbetsorientering och välmaiende. Den psykosociala betydelsen av arbetslöshet bland kvinnor och män. Doktorsavhandling. Umeå Universitet. Sociologiska Institutionen.

Nybom, J., Puide, A., Roselius, M. \& Hjulström, F. (red.).(2005). Förutsättningar för socialbidragsarbete: En jämförelse mellan fyra kommuner. Stockholm: Socialstyrelsen, Institutet för utveckling av metoder i socialt arbete.
Nybom, J. (2008). Hur bedömer socialarbetare socialbidragstagares försörjningshinder?

Socialvetenskaplig tidskrift, 15 (2), 152-169.

Nybom, J. (201 la). Activation in social work with social assistance claimants in four Swedish municipalities. European Journal of Social Work, 14,339-361.

Nybom, J. (2011b). Activation and 'coercion' among Swedish social assistance claimants with different work barriers and socio-demographic characteristics: what's the logic? International Journal of Social Welfare, 22, 45-57.

OECD. (1994). The OECD Jobs Study. Facts, analysis, strategies.

Palm A. \& van Eyck, W. (2007). Utvärdering av ungdomsslussen i Järfälla kommun. Stockholm: FoU Nordväst i Stockholms län.

Pavetti, L., Derr, M. K., \& Hesketh, H. (2003). Review of Sanction Policies and Research Studies - Final Literature Review. Washington, DC: Department of Health and Human Services.

Peck, L. (2007). What are the effects of welfare sanction policies? Or, using propensity scores as a subgroup indicator to learn more from social experiments. American Journal of Evaluation, 28, 256-273.

Proposition 1996/97:124. Ändring i Socialtjänstlagen.

Proposition 2012/13:94. Jobbstimulans inom det ekonomiska biståndet.

Riccio, J. \& Hasenfeld; Y. (1996). Enforcing a Participation Mandate in a Welfare-to-Work Program. Social Service Review, December, 516-542.

Puide, A. (1985). Klienterna och socialtjänsten. Doktorsavhandling. Stockholms universitet. Institutionen för socialt arbete.

Salonen, T. (2006). Socialt arbete med arbetslösa. I Denvall, V. \& Vinnerljung, B. (red). Nytta och fördärv. Socialt arbete $i$ kritisk belysning. Stockholm: Natur och Kultur.

Smedslund, G., Hagen, K. B., Steiro, A., Torill, J., Dalsbø, T. K., \& Rud, M. G. (2006). Work Programmes for Welfare Recipients. Campbell Systematic Reviews. 2006:9.

Socialstyrelsen. (2006). Social rapport 2006. Stock- 
holm: Socialstyrelsen.

Socialstyrelsen. (2010). Social rapport 2010. Stockholm: Socialstyrelsen.

SOU 2007:2. Från socialbidrag till arbete. Stockholm: Fritzes.

Stranz, H. \& Wiklund, S. (2011). I välfärdssamhällets marginal - om socialbidragstagande bland ensamstående mödrar av svensk och utländsk härkomst. Socialvetenskaplig tidskrift,18(1), 42-62.

Stenberg, S.-Å. (1998). Unemployment and Economic Hardship: A Combined Macro- and Micro-level Analysis of the Relationship between Unemployment and Means-tested Social Assistance in Sweden. European Sociolo gical Review, 14, 1-13.

Sunesson, S. (1981). När man inte lyckas. Om hinder, vanmakt och oförmåga $i$ socialt arbete. Stockholm:Almqvist \& Wiksell.

Sunesson, S. (2002). Sociala problem och samhällsbekymmer i historien. I Meeuwisse, A. \& Swärd, H. (red.). Perspektiv på sociala problem. Stockholm: Natur och Kultur.

Svedberg, L. (1994). En bok om marginalitet.
Stockholm: Stockholms universitet. Institutionen för socialt arbete.

Tengvald, T. (1995). Behov av resultatorienterad kunskapsutveckling $i$ socialt arbete. Kompetens och kunskapsutveckling. Delbetänkande av Socialtjänstkommittén (Bilaga i SOU 1995:58).

Ulmestig, R. (2006). På gränsen till fattigvård? En studie om arbetsmarknadspolitik och socialbidrag. Doktorsavhandling. Lunds universitet. Socialhögskolan.

Ulmestig, R. (2009). I arbetslinjens skugga - en studie av relationer och strukturer i ett kommunalt arbetsmarknadsprojekt. Växjö: Växjö universitet. Institutionen för vårdvetenskap och socialt arbete (Rapport i socialt arbete. No. 2. 2009).

van Berkel R. \& Møller, I. H. (red.) (2002). Active Social Policies in the EU. Inclusion through participation? Glasgow: The Policy Press.

van der Berg, G.J., van der Klaauw, B. \& van Ours, J.C. (2004). Punitive Sanctions and the Transition Rate from Welfare to Work. Journal of Labour Economics, 22 (1), 211-241. 


\section{Summary}

\section{How are activation and sanctions associated with work and social assistance need among social assistance recipients?}

This paper analyses how 351 social assistance claimants' participation in different types of activation programmes, and exposure to sanctions (rejection of social assistance due to non-compliance with activation requirement), during one year influenced their odds of getting work and to stay on social assistance the following two years. The social workers in each claimants' case were interviewed about activation and sanctions. The outcomes were followed up in national registers. According to the results, participation in activation consisting of education or work practice in regular workplaces had a positive correlation to work. Sanctions had a positive correlation to social assistance. The results of sanctions appeared to vary for different claimant groups or depending on the content of the activation programmes with which it was combined. 